\title{
Is there a role for high dose chemotherapy and blood stem cell rescue in childhood hepatoblastoma presenting with lung metastases? A case report and literature review
}

\author{
Massimo Provenzi ${ }^{1}$, Francesco Saettini ${ }^{*}$, Valentino Conter ${ }^{2}$, Eugenia Giraldi ${ }^{1}$, Carlo Foglia ${ }^{1}$, Laura Cavalleri ${ }^{1}$, \\ Michele Colledan ${ }^{3}$, Lorenzo D'Antiga', Giorgio Perilongo ${ }^{4}$ and Liviana Da Dalt ${ }^{4}$
}

\begin{abstract}
We report the use of high dose chemotherapy with peripheral blood stem cell rescue as a consolidation treatment for a 3-year-old child affected by metastatic hepatoblastoma, who achieved complete lung response only after conventional treatment. The patient is presently alive 27 months after high dose chemotherapy with blood stem cell rescue with no evidence of disease.

The role of high dose chemotherapy with blood stem cell rescue to consolidate the complete clearing of lung disease in metastatic hepatoblastoma remains controversial; the data available in the literature and our experience seems to suggest to keep this treatment option open to further consideration in the clinical setting of high-risk patients.
\end{abstract}

\section{Background}

Hepatoblastoma (HB) is the most common malignant liver tumor in children. Current multidrug chemotherapy regimens and surgery allow to obtain event free survival (EFS) and overall survival (OS) rates of approximately 70-80\% [1-4]. However, the outcome of children with metastatic tumor remains unsatisfactory, with EFS and OS of 25-38\% and $27-62 \%$ range respectively [2-11]. Intensification of conventional chemotherapy, notably with cisplatin (CDDP), and the use of innovative combinations of drugs in a "window setting", and more precisely, irinotecan and vincristine, are the two strategies adopted respectively by the European and North American cooperative study groups on HB to improve the present treatment outcome on these latter patients $[2,12]$.

In the literature the use of high dose chemotherapy (HDCT) with blood stem cell (BSC) rescue has been reported in children affected by metastatic HB in 21 cases. This report aiming to review the pertinent literature on

\footnotetext{
* Correspondence: francescosaettini@yahoo.it

${ }^{2}$ Department of Pediatrics, University of Milano-Bicocca, San Gerardo Hospital, Via Pergolesi 33, 20900 Monza, Italy

Full list of author information is available at the end of the article
}

this subject and our personal observation may serve to provide a more comprehensive understanding of the role of this therapeutic approach in children with $\mathrm{HB}$ and high-risk features of treatment failure, notably metastases, and potentially to support further stringent clinical investigation.

\section{Case presentation}

A three-year-old boy was referred to our center because of an asymptomatic abdominal mass. At the time of diagnosis, the alpha-feto protein (AFP) serum level was $192,269 \mathrm{ng} / \mathrm{mL}$ (normal value $<10 \mathrm{ng} / \mathrm{mL}$ ) and the platelet count $486,000 / \mathrm{mcl}$. The abdominal computed tomography $(\mathrm{CT})$ showed an intrinsic hepatic tumor mass involving extensively the right hepatic lobe (segment VI, VII and VIII). The mass was classified as PRETEXT II (tumor volume: $13 \times 12 \times 10 \mathrm{~cm}$ ) [13]. The surgical biopsy was in favor of an epithelial HB. The chest CT scan showed bilateral widespread metastatic lung disease. After obtaining informed consent, the patient was treated according to SIOPEL 4 protocol with CDDP $70 \mathrm{mg} / \mathrm{sqm}$ as a 24-hour continuous infusion (CI) on day 1,7 , and 14 (first dose of the first block CDDP at $80 \mathrm{mg} / \mathrm{sqm}$ as a 
24-hour CI) and doxorubicin (DOXO) $30 \mathrm{mg} / \mathrm{sqm}$ as a 48-hour CI on day 8 and 9; this block had to be repeated three times (omitting last CDDP) at one week interval. The abdominal CT scan performed thereafter exhibited a reduction of the extension of the hepatic mass $(7.5 \times 5.1 \times 4.5 \mathrm{~cm})$, now involving only segment VII and VIII, while the chest CT scan showed only a partial response (PR) of the lung lesions, which remained bilateral and widespread. The AFP level decreased to $588 \mathrm{ng} / \mathrm{ml}$. The surgical resection of the lung lesions was not performed because of the multifocality and the bilaterality of the disease. The patient underwent right hepatectomy and the histology was refined as a fetal $\mathrm{HB}$ with a rich macrotrabecular component ( $80 \%$ of the mass). The microscopic margins were clear. The AFP value further declined to $44.3 \mathrm{ng} / \mathrm{ml} 13$ days after surgery. Post-surgery chemotherapy consisted of carboplatin (CARBO) $500 \mathrm{mg} / \mathrm{sqm}$ on day 1,22 and 43, and DOXO $20 \mathrm{mg} / \mathrm{sqm}$ as a 24-hour CI on day $1,2,22,23,43$, and 44 . At the end of the treatment the AFP returned to normal $(7.7 \mathrm{ng} / \mathrm{ml})$ and the chest CT scan revealed no signs of residual lung disease.

Fearing that the late response of the metastases (i.e. at least a partial response to preoperative chemotherapy and complete remission of pulmonary metastases only after postoperative chemotherapy, regardless AFP levels) could be a dismal prognostic factor it was elected, with parental agreement, to complete therapy with a course of HDCT and peripheral BSC rescue. Autologous BSC were harvested in 2 days (total $1.3 \times 10^{6}$ and $3 \times 10^{6}$ CD34+ cells $/ \mathrm{kg}$ ), after G-CSF stimulation. As used in our center for other metastatic solid tumors, the conditioning regimen consisted of CARBO $500 \mathrm{mg} / \mathrm{sqm} /$ die from day -5 to day -3 ; etoposide $300 \mathrm{mg} / \mathrm{sqm} /$ die from day -5 to day -3 ; melphalan $120 \mathrm{mg} / \mathrm{sqm} /$ die on day -2 . On day 0 and day $+1 \mathrm{BSC}\left(3 \times 10^{6}\right.$ and $1.3 \times 10^{6} \mathrm{CD} 34+$ cells $\left./ \mathrm{kg}\right)$ were infused. From day +4 to day +14 G-CSF was given; neutrophil count was over $500 / \mathrm{mm}^{3}$ since day +12 while platelet engraftment $(>20000 / \mathrm{mcl}$, transfusion independent) was documented from day +13 . Toxicity was modest and represented by mucositis and fever of unknown origin. Presently the patient remains disease-free, with normal AFP levels and no radiological evidence of disease, 27 months following HDCT with peripheral BSC rescue.

\section{Summary of the literature}

The use of HDCT with BSC rescue has been used in a number of patients with $\mathrm{HB}$ at the time of tumor recurrence [10,14-18], but in only 22 of them, including the one here reported, as a first line treatment in patients with metastatic disease $[14,15,19,20]$. These 22 patients represent the focus of this report. In 2 of them a double autologous BSC rescue instead of conventional postoperative chemotherapy was performed; one of these underwent BSC rescue with persisting lung involvement. Both patients relapsed, but interestingly one of them was then rescued with irinotecan alone [14]. Fourteen patients did not achieve PR of the target lesions after conventional pre-operative chemotherapy (POC) and without further specifications regarding the tumor status at the time of HDCT all were then treated with HDCT with BSC rescue. Of these patients 2 died of toxicity of the procedure and only 4 were reported alive with no evidence of disease [20].

The last subgroup of children of whom we have detailed information encompasses 6 patients who achieved at least a PR after POC, and after conventional partial hepatectomy and post-operative chemotherapy underwent HDCT with BSC rescue, while in complete remission (CR) of lung metastases (see Table 1).

In these group of children four of them obtained complete clearance of metastases with POC but presented with persisting high serum levels of AFP after post-operative chemotherapy; three of these four patients at the time of the report were alive and disease-free 16 months after BSC rescue, with normal AFP levels, while one displayed continuously increasing AFP and ultimately died of brain metastases [19]. One case presenting with multiple metastatic disease that completely responded to POC is reported alive and disease-free six years from stopping therapy [15]. Our patient was a late

Table 1 High dose chemotherapy with blood stem cell rescue following post-operative chemotherapy for metastatic HB patients achieving partial response after pre-operative chemotherapy

\begin{tabular}{|c|c|c|c|c|c|c|c|}
\hline $\begin{array}{l}\text { Reference and number of } \\
\text { patients }\end{array}$ & Age/Sex & PRETEXT & $\begin{array}{l}\text { Previous } \\
\text { regimen }\end{array}$ & $\begin{array}{l}\text { Tumor status at the } \\
\text { time of HDCT }\end{array}$ & $\begin{array}{l}\text { Conditioning } \\
\text { regimen }\end{array}$ & $\begin{array}{l}\text { BSC } \\
\text { source }\end{array}$ & Outcome \\
\hline $\begin{array}{l}\text { Matsunaga T [19]: } \\
4 \text { patients }\end{array}$ & Unknown & Any PRETEXT M+ & $\begin{array}{l}\text { CDDP, THP- } \\
\text { ADR }\end{array}$ & $\mathrm{AFP} \uparrow$ & CARBO, VP16, MLP & PB & $\begin{array}{l}3 \text { NED } 16 \text { mts after } \\
\text { BSC rescue } 1 \text { DoD }\end{array}$ \\
\hline $\begin{array}{l}\text { Nishimura SI [15]: } \\
1 \text { patient }\end{array}$ & $10 \mathrm{yr} / \mathrm{M}$ & IV M+ & CDDP, DOXO & NED & $\begin{array}{l}\text { DOXO, VP16, } \\
\text { CARBO, 5-FU }\end{array}$ & $\mathrm{BM}$ & $\begin{array}{l}\text { NED } 6 \text { yr after BSC } \\
\text { rescue }\end{array}$ \\
\hline $\begin{array}{l}\text { Provenzi M 2013: } \\
1 \text { patient }\end{array}$ & $3 \mathrm{yr} / \mathrm{M}$ & $\| \mathrm{M}+$ & CDDP, DOXO & NED & CARBO, VP16, MLP & PB & $\begin{array}{l}\text { NED } 27 \text { mts after } \\
\text { BSC rescue }\end{array}$ \\
\hline
\end{tabular}

Abbreviations: BSC blood stem cell, $M+$ lung metastases, CDDP cisplatin, THP-ADR THP-adriamicin, AFP alpha-feto protein, CARBO carboplatin, VP16 etoposide, $M L P$ melphalan, $P B$ peripheral blood, NED no evidence of disease, $m t s$ months, DoD died of disease, yr years, $D O X O$ doxorubicin, $5-F U 5$ fluorouracil, $B M$ bone marrow. 
responder to conventional chemotherapy and, as described, is alive with no evidence of disease 27 months after BSC rescue. Thus as overall five of these 6 patients had been reported to be alive with no evidence of disease with a minimum follow-up of 16 months after BSC rescue.

This small series of twenty-two patients cannot provide a comprehensive view of the role of HDCT with BSC rescue in the treatment of HB. However, the fact that 5 out of the 6 children achieved at least a PR after conventional POC and received HDCT with autologous BSC rescue while in $\mathrm{CR}$ of lung metastases at the end of conventional treatment seems to indicate a possible role of this treatment modality in the management of these patients.

\section{Conclusions}

The experiences here reported may suggest thus that HDCT with autologous BSC rescue can be of benefit for patients with metastatic $\mathrm{HB}$ who achieved at least a PR after POC, as a consolidation of a CR of lung metastases otherwise achieved at the end of treatment. Moreover HDCT and BSC rescue can be feasible in patients who have already received intensive conventional chemotherapy but the underlying possible severe toxicity of this modality should be clearly kept in mind and parents should be closely involved in the decision process. Of course nobody knows if in these children the previous treatment, which allowed them to achieve the complete tumor response, would have been enough for the cure. However, considering that late response to chemotherapy is indeed a matter of concern in all tumor types, to have presented the series herewith reported could serve to keep the treatment option of using HDCT with BSC rescue of children affected by metastatic $\mathrm{HB}$ open to further clinical investigation.

\section{Consent}

Written informed consent was obtained from the parents of the patients for publication of this Case report. A copy of the written consent is available for review by the Editor-in-Chief of this journal.

\section{Abbreviations}

AFP: Alpha-feto protein; BSC: Blood stem cell; CARBO: Carboplatin; CDDP: Cisplatin; Cl: Continuous infusion; CT: Computed tomography; CR: Complete remission; DOXO: Doxorubicin; EFS: Event free survival; HB: Hepatoblastoma; HDCT: High dose chemotherapy; OS: Overall survival; POC: Pre-operative chemtherapy; PR: Partial response.

\section{Competing interests}

The authors declare they have no competing interests.

\section{Authors' contributions}

MP, FS, VC and GP conceived the study, drafted the manuscript and evaluated all the children. EG, CF, CF and MC contributed to data acquisition and drafting of the article. LDA and LDD contributed to critical revision of the article and to final approval of the version to be published. All authors read and approved the final manuscript.

\section{Acknowledgements}

The authors are indebted with Dr. Rupert Handgretinger for sharing with us the choice of the treatment strategy in this patient.

\section{Author details}

'Department of Pediatrics, Ospedale Papa Giovanni XXIII, Bergamo, Italy. ${ }^{2}$ Department of Pediatrics, University of Milano-Bicocca, San Gerardo Hospital, Via Pergolesi 33, 20900 Monza, Italy. ${ }^{3}$ Department of Surgery, Ospedale Papa Giovanni XXIII, Bergamo, Italy. ${ }^{4}$ Department of Woman's and Child's Health, University Hospital of Padua, Padua, Italy.

Received: 9 August 2013 Accepted: 18 October 2013

Published: 22 October 2013

\section{References}

1. Perilongo G, Maibach R, Shafford E, Brugieres L, Brock P, Morland B, de Camargo B, Zsiros J, Roebuck D, Zimmermann A, Aronson D, Childs M, Widing E, Laithier V, Plaschkes J, Pritchard J, Scopinaro M, MacKinlay G, Czauderna P: Cisplatin versus cisplatin plus doxorubicin for standard risk hepatoblastoma. N Engl J Med 2009, 361:1662-1670.

2. Zsiros J, Maibach R, Shafford E, Brugieres L, Brock P, Czauderna P, Roebuck D, Childs M, Zimmermann A, Laithier V, Otte JB, de Camargo B, MacKinlay G, Scopinaro M, Aronson D, Plaschkes J, Perilongo G: Successful treatment of childhood high-risk hepatoblastoma with dose-intensive multiagent chemotherapy and surgery: final results of the SIOPEL 3-HR study. J Clin Oncol 2010, 28:2584-2590.

3. Trobaugh-Lotrario AD, Katzenstein HM: Chemotherapeutic approaches for newly diagnosed hepatoblastoma: past, present, and future strategies. Pediatr Blood Cancer 2012, 59:809-812.

4. Malogolowkin MH, Katzenstein HM, Krailo M, Meyers RL: Treatment of hepatoblastoma: the North American cooperative group experience. Front Biosci 2012, 4:1717-1723.

5. Maibach R, Roebuck D, Brugieres L, Capra M, Brock P, Dall'Igna P, Otte JB, De Camargo B, Zsiros J, Zimmermann A, Aronson D, Childs M, Scopinaro M, Morland B, Plaschkes J, Czauderna P, Perilongo G, et al: Prognostic stratification for children with hepatoblastoma: the SIOPEL experience. Eur J Cancer 2012, 48:1543-1549.

6. Pritchard J, Brown J, Shafford E, Perilongo G, Brock P, Dicks-Mireaux C, Keeling J, Phillips A, Vos A, Plaschkes J, et al: Cisplatin, doxorubicin, and delayed surgery for childhood hepatoblastoma: a successful approach results of the first prospective study of the international society of pediatric oncology. J Clin Oncol 2000, 18:3819-3828.

7. Perilongo G, Shafford E, Maibach R, Aronson D, Brugières L, Brock P, Childs M, Czauderna P, MacKinlay G, Otte JB, Pritchard J, Rondelli R, Scopinaro M, Staalman C, Plaschkes J, International Society of Paediatric Oncology-SIOPEL 2: Risk-adapted treatment for childhood hepatoblastoma: Final report of the second study for the International Society of Pediatric Oncology SIOPEL 2. Eur J Cancer 2004, 40:411-421.

8. Ortega JA, Douglass EC, Feusner JH, Feusner JH, Reynolds M, Quinn JJ, Finegold MJ, Haas JE, King DR, Liu-Mares W, Sensel MG, Krailo MD: Randomized comparison of cisplatin/vincristine/fluorouracil and cisplatin/continuous infusion doxorubicin for treatment of pediatric hepatoblastoma: a report from the Children's cancer group and the pediatric oncology group. J Clin Oncol 2000, 18:2665-2675.

9. Fuchs J, Rydzynski J, Von Schweinitz D, Bode U, Hecker H, Weinel P, Bürger D, Harms D, Erttmann R, Oldhafer K, Mildenberger H, Study Committee of the Cooperative Pediatric Liver Tumor Study Hb94 for the German Society for Pediatric Oncology and Hematology: Pretreatment prognostic factors and treatment results in children with hepatoblastoma: a report from the German cooperative pediatric liver tumor study HB 94. Cancer 2002, 95:172-182.

10. Katzenstein HM, London WB, Douglass EC, Reynolds M, Plaschkes J, Finegold MJ, Bowman LC: Treatment of unresectable and metastatic hepatoblastoma: a pediatric oncology group phase II study. J Clin Oncol 2002, 20:3438-3444.

11. Haberle B, Bode U, von Schweinitz D: Differentiated treatment protocols for high- and standard-risk hepatoblastoma: An interim report of the German Liver Tumor Study HB99 [German]. Klin Padiatr 2003, 215:159-165.

12. Bomgaars LR, Bernstein M, Krailo M, Kadota R, Das S, Chen Z, Adamson PC, Blaney SM: Phase II trial of irinotecan in children with refractory solid 
tumors: a Children's oncology group study. J Clin Oncol 2007,

25:4622-4627.

13. Aronson DC, Schnater JM, Staalman CR, Weverling GJ, Plaschkes J, Perilongo G, Brown J, Phillips A, Otte JB, Czauderna P, MacKinlay G, Vos A: Predictive value of the pretreatment extent of disease system in hepatoblastoma: results from the international society of pediatric oncology liver tumor study group SIOPEL-1 study. J Clin Oncol 2005, 23:1245-1252.

14. Katzenstein HM, Rigsby C, Shaw PH, Mitchell TL, Haut PR, Kletzel M: Novel therapeutic approaches in the treatment ofChildren with hepatoblastoma. J Pediatr Hematol Oncol 2002, 24:751-755.

15. Nishimura S, Sato T, Fujita N, Hiyama E, Yokoyama T, Ueda K: High-dose chemotherapy in children with metastatic hepatoblastoma. Pediatr Int 2002, 44:300-305.

16. Hara J, Osugi Y, Ohta H, Matsuda Y, Nakanishi K, Takai K, Fujisaki H, Tokimasa S, Fukuzawa M, Okada A, Okada S: Double-conditioning regimens consisting of thiotepa, melphalan and busulfan with stem cell rescue for the treatment of pediatric solid tumors. Bone Marrow Transplant 1998, 22:7-12.

17. Niwa A, Umeda K, Awaya T, Matsubara H, Hiramatsu H, Watanabe K, Adachi S, Itoh T, Uemoto S, Nakahata T: Successful autologous peripheral blood stem cell transplantation with a double-conditioning regimen for recurrent hepatoblastoma after liver transplantation. Pediatr Transplantation 2009, 13:259-262

18. Yoshinari M, Imaizumi M, Hayashi Y, Sato A, Saito T, Suzuki H, Saisho T, Abukawa D, Ogawa E, Aikawa J, Goto K, Satoh T, Ohi R, Linuma K: Peripheral blood stem cell transplantation for hepatoblastoma with microscopic residue: A therapeutic approach for incompletely resected tumor. Tohuku J Exp Med 1998, 184:247-254.

19. Matsunaga T, Sasaki F, Ohira M, Hashizume K, Hayashi A, Hayashi Y, Mugishima H, Ohnuma N, Japanese Study Group for Pediatric Liver Tumor: Analysis of treatment outcome for children with recurrent or metastatic hepatoblastoma. Pediatr Surg Int 2003, 19:142-146.

20. Hishiki T, Matsunaga T, Sasaki F, Yano M, Ida K, Horie H, Kondo S, Watanabe K, Oue T, Tajiri T, Kamimatsuse A, Ohnuma N, Hiyama E: Outcome of hepatoblastomas treated using the Japanese Study Group for Pediatric Liver Tumor (JPLT) protocol-2: report from the JPLT. Pediatr Surg Int 2011, 27:1-8.

doi:10.1186/1824-7288-39-65

Cite this article as: Provenzi et al: Is there a role for high dose chemotherapy and blood stem cell rescue in childhood hepatoblastoma presenting with lung metastases? A case report and literature review. Italian Journal of Pediatrics 2013 39:65.

\section{Submit your next manuscript to BioMed Central and take full advantage of:}

- Convenient online submission

- Thorough peer review

- No space constraints or color figure charges

- Immediate publication on acceptance

- Inclusion in PubMed, CAS, Scopus and Google Scholar

- Research which is freely available for redistribution

Submit your manuscript at www.biomedcentral.com/submit
(O) Biomed Central 